\title{
The south american context of diagnostic disclosure of adolescents infected by HIV/AIDS: a systematic literature review
}

\author{
(DD Patrícia Neuva da Costa Pinheiro' \\ (iD) Bernard Carl Kendall ${ }^{2}$ \\ (D) Ligia Regina Franco Sansigolo Kerr ${ }^{3}$ \\ (iD) Keith Michael Pickett ${ }^{4}$ \\ (iD) Izaildo Tavares Luna ${ }^{1}$ \\ (D) Maria Isabelly Fernandes da Costa ${ }^{1}$ \\ (iD) Luisa Fânia da Costa Luz
}

1. Universidade Federal do Ceará - UFC, Fortaleza, CE, Brasil. 2. Tulane University, Research Support \& Education Librarian - Tulane, New Orleans, EUA 3. Doutora em Medicina pela Universidade de Ribeirão Preto. Professora titular da Universidade Federal do Ceará - UFC, Fortaleza, CE, Brasil. 4. Master of Library and Information Science. Research Support \& Education Librarian, Tulane University, New Orleans, LA, EUA. 5. Licenciada em Letras. Especialista em Língua Portuguesa pela Universidade Estadual do Ceará - UECE, Fortaleza, CE, Brasil.

http://dx.doi.org/10.1590/1806-9282.66.8.1139

\section{SUMMARY}

OBJECTIVE: To analyze the scientific evidence on the disclosure of the diagnostic of adolescents infected by HIV/AIDS in the South American context.

DATABASE: Systematic literature review using the PubMed, Cinahal, Embase, Cochrane, BVS, and Global Health databases and the descriptors: adolescent and HIV and family and Argentina or Bolivia or Brasil or Chile or Colombia or Ecuador or French Guiana or Paraguay or Peru or Uruguay or Venezuela.

DATA SYNTHESIS: Brasil was the country highlighted. It was verified that parents have a direct and indirect influence over the adolescents' life, especially regarding behaviors and health care. Dialog among family members can reduce adolescents' vulnerability to HIV and encourage diagnostic disclosure.

CONCLUSION: It is necessary to amplify research involving adolescents with HIV/AIDS and their parents/caregivers and family members to improve care and reduce the cases of the disease. It is suggested that policies of prevention and treatment should involve families, caregivers, partners, and the community.

KEYWORDS: Family. Adolescent. HIV. South America.

\section{INTRODUCTION}

Adolescence is characterized by various transformations that permeate the biological, psychological, social, and emotional aspects that influence decision making regarding adulthood and the construction of individual, sexual, and social identity. ${ }^{1.2}$ The changes that occur in the life of adolescents expose them to the 
most diverse types of vulnerabilities, among these, the infection by HIV/aids. ${ }^{3}$

HIV/AIDS is considered a serious public health issue, and among adolescents it becomes even more worrying, considering the incidence of over 2,400 adolescents/young people infected daily and the over 10 million people aged between 15 and 24 years living with HIV/aids worldwide. The index of aids among young people and adolescents aged from 15 to 19 years increased from 2.8 cases per 100 thousand inhabitants to 5.8 cases. ${ }^{4}$ In addition, aids is considered the eighth leading cause of death among adolescents throughout the world, and its prevention and treatment are some of the most important challenges for public health. ${ }^{5}$

The strategies targeted at the prevention and treatment of seropositive adolescents are directly linked to their families, considering that the participation of this support network influences the treatment, with adherence to the antiretroviral therapy (ART) and changes in routine and behaviors, often based on beliefs, values, and habits learned from an early age. ${ }^{6}$

However, crises arising from difficulties in the relationship between parents and adolescents are closely related to the absence of dialog and difficulty of understanding between these two worlds. In this sense, parents and children create barriers for dialog, as a result, adolescents seek other sources of information, mainly friends and the media. ${ }^{7.8}$

Dialog can be an important tool when it comes to safe sex practices since the family can positively contribute to prevention and treatment, minimizing prejudices and taboos related to the coexistence with a seropositive adolescent. Thus, it is necessary to have an open and welcoming dialog, especially during the disclosure of the diagnosis. In addition, it is necessary to highlight the importance of research on the disclosure of diagnosis that results in evidence that provides refuge to adolescents infected by HIV. ${ }^{9.10}$

Thus, this study aims to analyze the scientific evidence on the disclosure of the diagnosis of adolescents infected by HIV/aids in a South-American scenario.

\section{METHODS}

A systematic review of the literature was carried out outlined by the Preferred Reporting Items for Systematic Reviews and Meta-Analyses (Prism), organized and completed independently by the researchers. ${ }^{11}$ The search was performed in the following databases: PubMed, Cinahal (Cumulative Index to Nursing \&
Allied Health Literature), Embase (Excerpta Medica para banco de dados), Cochrane (Central Register of Controlled Trials), BVS (Biblioteca Virtual em Saúde), and Global Health, using the controlled descriptors indexed in the DeCS (Descritores em Ciências da Saúde) $)^{12}$ along with the name of each country, in April and May 2014.

The descriptors used in the search were: adolescent and HIV and family and Argentina or Bolivia or Brasil or Chile or Colombia or Equador or French Guiana or Paraguay or Peru or Uruguay or Venezuela. Only the boolean operator (delimiter) and was used, assuming that, during the search, each country acted uniquely in the combination with the other descriptors.

We used End Note ${ }^{R}$, an online tool for managing references integrated with the Web of Knowledge, and various databases as aiding tools for data organization. To achieve the objective proposed, a question was formulated based on the PICO (Patient Intervention Comparison Outcome) strategy: What is the scientific evidence published in the following databases on the disclosure of the diagnosis of South American adolescents infected by HIV/AIDS?

We compared a database of 430 papers generated by the keywords adolescent and HIV and family and names of South American countries, with a database of 4,553 papers generated by the descriptors adolescent and HIV and names of South American countries and there were no differences, i.e., the papers found were the same. It is necessary to highlight that these studies were all carried out in Brasil. The analysis of the studies was carried out independently, based on their critical reading and the interpretation of the information, comparing the findings with the literature.

\section{RESULTS}

In total, 430 papers were found; however, from the reading of their titles, 415 were excluded, remaining only 15 papers. Of these, five were duplicated, so there were ten papers left. After reading the abstracts, four papers were excluded (extended abstract in annals; population of the study related to children up to 6 months of age; research conducted in Canada and without any relation with South American countries, and a book chapter). Of the six papers selected, all were carefully read and none were excluded (Figure 1).

Among the six studies, there was a prevalence of studies published in 2008, followed by 2006, 2012, and 2013. The summary of the six studies identified 
regarding their authors, years, periodicals, titles, designs, locations, and samples are presented in Table 1. The scope, intervention, comparison, results, and evidence can be found in Table 2 .

Regarding the design of the studies, qualitative studies were prevalent, and there was only a single quantitative study. The sample comprised 338 adolescents; of these, 296 were part of the cross-sectional quantitative study, and 42 were distributed in the qualitative studies, ranging from 4 to 22 adolescents per study. Among the 12 South American countries, only Brasil, most prominently the state of São Paulo, had studies that met our criteria.

The disclosure of the diagnosis was considered a milestone in the life of adolescents and is permeated by the fear of prejudice and social isolation, in addition to influencing the quality of life of adolescents and their families. Vertically infected adolescents receive a different treatment, and the adherence to the treatment and questions made were considered facilitators.

However, it was observed that adolescents who live with their parents are less exposed to risk situations; it is considered that the influence of parents
FIGURE 1. FLOWCHART OF PAPER IDENTIFICATION AND SELECTION FOR A SYSTEMATIC REVIEW ON THE ROLE OF FAMILIES WITH ADOLESCENTS IN THE CONTEXT OF SOUTH AMERICAN COUNTRIES, 2014.

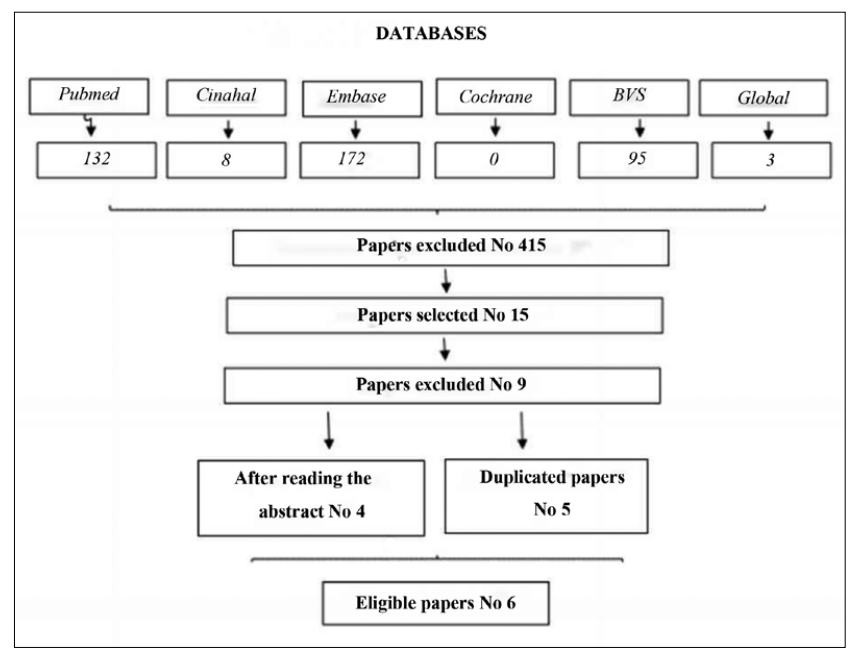

contributes to the building and adoption of healthy behaviors among adolescents. However, the difficulty in dialogs on sex and sexuality exposes adolescents to situations of vulnerability. This difficulty in dialog may be associated with low parental schooling.

TABLE 1. CHARACTERISTICS OF STUDIES ON THE FAMILIES OF ADOLESCENTS INFECTED BY HIV/AIDS IN BRASIL, 1996 TO 2014

\begin{tabular}{|c|c|c|c|}
\hline Code & Author, Year, Place & Title/ Journal & Design/Sample/Problem \\
\hline 1 & $\begin{array}{l}\text { Marques et al., 2006; } \\
\text { São Paulo and Santos }\end{array}$ & $\begin{array}{l}\text { Disclosure of HIV infection from the perspective of } \\
\text { adolescents living with HIV/aids and their parents and } \\
\text { caregivers- Cad. Saúde Pública }\end{array}$ & $\begin{array}{l}\text { - Qualitative; Study; } 22 \text { adolescents and } 13 \text { cares - } \\
\text { HIV Seropositivity }\end{array}$ \\
\hline 2 & $\begin{array}{l}\text { Peres et al., 2008; } \\
\text { São Paulo }\end{array}$ & $\begin{array}{l}\text { Family Structure and Adolescent Sexual Behavior in } \\
\text { a Poor Area of São Paulo, Brazil- Journal of Adolescet } \\
\text { Health }\end{array}$ & $\begin{array}{l}\text { - Cross-sectional study; } 296 \text { young people/adoles- } \\
\text { cents- Vulnerability to HIV }\end{array}$ \\
\hline 3 & $\begin{array}{l}\text { Lima \& Pedro, 2008; } \\
\text { Porto Alegre, RS }\end{array}$ & $\begin{array}{l}\text { Growing up with HIV/aids: a study on adolescents with } \\
\text { HIV/aids and their family caregivers-Rev Latino-am } \\
\text { Enfermagem }\end{array}$ & $\begin{array}{l}\text { Exploratory study with a qualitative approach - } \\
\text { Growth and development with HIV }\end{array}$ \\
\hline 4 & $\begin{array}{l}\text { Barbosa et al., 2008; } \\
\text { Fortaleza }\end{array}$ & $\begin{array}{l}\text { Stages of change in parents discussions with their } \\
\text { children about HIV/aids prevention- Revista Latino } \\
\text { America de Enfermagem }\end{array}$ & - HIV Prevention \\
\hline 5 & $\begin{array}{l}\text { Galano et al., 2012; } \\
\text { São Paulo }\end{array}$ & $\begin{array}{l}\text { Interviews with family members: the essential tool for } \\
\text { planning the disclosure of the diagnosis of HIV/aids for } \\
\text { children and adolescents- Ciência \& Saúde Coletiva }\end{array}$ & $\begin{array}{l}\text { Qualitative study; } 23 \text { parents/relatives- HIV Sero- } \\
\text { positivity }\end{array}$ \\
\hline 6 & $\begin{array}{l}\text { Cammarano Ribeiro } \\
\text { et al., 2013; Rio } \\
\text { Grande do Sul }\end{array}$ & $\begin{array}{l}\text { Therapeutic everyday of adolescent who has HIV/aids: } \\
\text { self-caring occupation and family solitude- Ciência, } \\
\text { Cuidado \& Saúde }\end{array}$ & $\begin{array}{l}\text { Qualitative study with phenomenological approach } \\
\text { and philosophical theoretical methodological; } 16 \\
\text { adolescents- Growth and development with HIV }\end{array}$ \\
\hline \multicolumn{4}{|c|}{ References: } \\
\hline \multicolumn{4}{|c|}{$\begin{array}{l}\text { 1. Marques HHS, Silva NG, Gutierrez PL, Lacerda R, Ayres JRCM, DellaNegra M et al. A revelação do diagnóstico na perspectiva dos adolescentes vivendo com HIV/AIDS e seus } \\
\text { pais e cuidadores. Cad. Saúde Pública [Internet]. } 2006 \text { Mar [cited } 2020 \text { Apr 16]; 22(3): 619-629. }\end{array}$} \\
\hline \multicolumn{4}{|c|}{$\begin{array}{l}\text { 2. Peres CA, Rutherford G, Borges G, Galano E, Hudes ES, Hearst N. Family structure and adolescent sexual behavior in a poor area of São Paulo, Brazil. J Adolesc Health [Internet]. } \\
2007 \text { Feb [cited } 2020 \text { Apr 16]; 42(2):177-83. }\end{array}$} \\
\hline \multicolumn{4}{|c|}{$\begin{array}{l}\text { 3. Lima AAA, Pedro ENR. Growing up with HIV/AIDS: a study on adolescents with HIV/AIDS and their family caregivers. Rev. Latino-Am. Enfermagem [Internet]. } 2008 \text { June } \\
\text { [cited } 2020 \text { Apr 16]; 16(3): 348-354. }\end{array}$} \\
\hline \multicolumn{4}{|c|}{$\begin{array}{l}\text { 4. Barbosa SM, Costa PNP, Vieira NFC. Stages of change in parents' discussions with their children about HIV/Aids prevention. Rev. Latino-Am. Enfermagem [Internet]. 2008 } \\
\text { Dec [cited } 2020 \text { Apr 16]; 16(6): 1019-1024. }\end{array}$} \\
\hline \multicolumn{4}{|c|}{$\begin{array}{l}\text { 5. Galano E, De Marco MA, Succi RCM, Silva MH. da, Machado Daisy Maria. Entrevista com os familiares: um instrumento fundamental no planejamento da revelação diagnóstica } \\
\text { do HIV/Aids para crianças e adolescentes. Ciênc. saúde coletiva [Internet]. } 2012 \text { Oct [cited } 2020 \text { Apr 16]; 17(10): 2739-2748. }\end{array}$} \\
\hline \multicolumn{4}{|c|}{$\begin{array}{l}\text { 6. Ribeiro AC, Padion SMM, Paula CC, Mota MGC. Therapeutic everyday of adolescent who has hiv/aids: self-caring occupation and family solitude. Ciênc. cuid. saúde [Internet]. } \\
2013 \text { [cited } 2020 \text { Apr 16]; 12(1): 139-145. }\end{array}$} \\
\hline
\end{tabular}


TABLE 2. CHARACTERISTICS OF STUDIES ON FAMILY AND TEENAGERS IN THE SCENARIO OF THE AIDS PANDEMIC, ACCORDING TO PROBLEM, INTERVENTION(S), COMPARISON, RESULTS, AND EVIDENCE, BRASIL, 1996 TO 2014.

\begin{tabular}{|c|c|c|}
\hline Intervention & Code/Comparison & Result/Evidence \\
\hline 1 & $\begin{array}{l}\text { Disclosure of the diag- } \\
\text { nosis/ Enhancing Care } \\
\text { Initiative }(\mathrm{ECl})\end{array}$ & $\begin{array}{l}\text { The disclosure of the diagnosis is a milestone in the life of the adolescents and families. The fear } \\
\text { of prejudice, discrimination, and social isolation are complicating factors in the disclosure of the } \\
\text { diagnosis. On the other hand, the need for adherence to treatment and questions are facilitators. } \\
\text { Adolescents who became infected by vertical transmission have different care in comparison to } \\
\text { others. The demand is created by the family and health team. }\end{array}$ \\
\hline 2 & $\begin{array}{l}\text { Influence of parents on } \\
\text { the behavior of children/ } \\
\text { Studies from Latin Amer- } \\
\text { ica, Caribbean and United } \\
\text { States }\end{array}$ & $\begin{array}{l}\text { Adolescents living with parents are less exposed to risks. The influence of one or both parents } \\
\text { in the life of adolescents contributes to reducing the risks to which they are exposed. Efforts } \\
\text { focused on the reduction of risks in adolescence should involve the parents. }\end{array}$ \\
\hline 3 & $\begin{array}{l}\text { Treatment, disclosure of } \\
\text { the diagnosis, influence of } \\
\text { parents and teachers; }\end{array}$ & $\begin{array}{l}\text { Changes in the quality of life of adolescents and their relatives. } \\
\text { Changes in lifestyle due to the treatment and care. Confidentiality regarding the disclosure of the } \\
\text { diagnosis to society for fear of prejudice, discrimination, and social isolation. No approach from } \\
\text { the family, school and health services regarding bodily changes, sexual and reproductive health } \\
\text { of these adolescents. Strong influence of the media. }\end{array}$ \\
\hline 4 & Dialog & $\begin{array}{l}\text { Adolescents are vulnerable to risks because parents find it difficult to talk with their children } \\
\text { about sex/sexuality. Mothers are more present than fathers in the education of their children. } \\
\text { Low parental schooling hinders dialog. The inability of parents to establish dialog increases } \\
\text { adolescents' vulnerability to HIV/aids. Efforts focused on the prevention of HIV should involve } \\
\text { adolescents, families, schools, and health units. }\end{array}$ \\
\hline 5 & $\begin{array}{l}\text { Disclosure of the diagnosis; } \\
\text { Handbook prepared by } \\
\text { members of the Institute } \\
\text { of Health of New York }\end{array}$ & $\begin{array}{l}\text { The decision to disclose the diagnosis is a slow and painful process Fear of prejudice, discrimi- } \\
\text { nation, and social isolation, guilt, changes in mental health, and desire to live are complicating } \\
\text { factors in the disclosure of diagnosis. On the other hand, the need for adherence to treatment, } \\
\text { the ability to keep a secret, and questions are facilitators. }\end{array}$ \\
\hline 6 & Treatment & $\begin{array}{l}\text { Changes in the quality of life of adolescents. } \\
\text { Changes in lifestyle due to the treatment and care. Need for strengthening of self-care strategies. } \\
\text { Family was the main support source. }\end{array}$ \\
\hline
\end{tabular}

\section{DISCUSSION}

The disclosure of the diagnosis as a milestone in the life of the adolescents and their families was one of the main findings of the study. Three of the six studies addressed the disclosure of the diagnosis, with emphasis on studies carried out at Harvard University and the Merck Foundation. Some countries became participants of this project, among them Brasil (São Paulo and Santos), Senegal (Dakar), South Africa (KwaZulu-Natal), Thailand (Northern Region), and Puerto Rico. Ten priority areas of care were established, among them, the service diagnosis support to adolescents and nine recommendations to improve health care services for adolescents and their caregivers, highlighting relevant aspects such as the importance of raising awareness about the rights of young people, improving dialogs about stigmatization and discrimination, providing clear and updated information, and involving family members and close friends in the process of disclosure of the diagnosis. ${ }^{13}$

It is possible to have subsidies to disclose the diagnosis, with proper support, thus minimizing the negative aspects and strengthening the positive ones. The main negative factors that hinder the disclosure of the diagnosis were stigma, prejudice, and discrimination; the positive ones were adherence to the treatment and care..$^{2.4}$

The stigma, prejudice, and discrimination experienced by many people living with HIV/aids and their families have been discussed internationally, mainly by the United States, since it has a discriminatory and exclusive nature that can compromise the life conditions and health of individuals and communities. ${ }^{14}$

Therefore, this stage of the lives of theses adolescents requires care, efficiency, and awareness of the professionals and families involved. It is important to take into account the influence of parents in their children's risky behaviors because this has a direct and indirect impact on the lifestyle and daily routines of seropositive adolescents.

One of the studies that stood out was developed by the Aids Institute of the New York State Department of Health and included the preparation of a handbook with recommendations on the disclosure of the diagnosis, the type of approach, best time, need for a multi-professional team and family support. The handbook also covers intra-related topics, such as that of caregivers to establish a care plan, specific ages and considerations for the disclosure; ways to prepare the family, considerations for disclosure with adolescents, and monitoring and support visits to adolescents. ${ }^{15}$ 
This condition, caused by disadvantaged situations, such as seropositivity for HIV, can lead to social rejection and endanger the physical and mental health of individuals. Therefore, social psychology seeks to highlight ways of tackling stigma, prejudice, and discrimination. ${ }^{16}$ However, oftentimes, this aspect is not valued, considering the great importance given to studies on the perception of risk and behaviors in specific groups and, in particular, on the adherence to the treatment. ${ }^{16}$

The possibility of better adherence to treatment, through awareness and positive health behavior, is seen as a positive factor that encourages the disclosure of the diagnosis. It is known that adequate adherence to highly active antiretroviral therapy (ARVT), introduced in 1996, has had a major positive impact in the reduction of morbidity and mortality of people with HIV/aids. In Brasil, it has reduced mortality by approximately $70 \%$ and the incidence of opportunistic infections by $80 \% .{ }^{17}$ However, adherence to the treatment has many complicating factors, such as the conciliation between the daily activities, treatment demands, and the negative connotation that HIV and ARVT have to many individuals.

ARVT influences the prevalence of hyperlipidemia and the redistribution of fat during puberty, being significantly associated with sexual maturity. Changes in the body and self-perception have both hampered the adherence to the treatment as well as increased the incidence of depression. Thus it is necessary to have, in this process, the guidance and support of parents and caregivers, creating support groups and networks, as well as training the professionals involved. ${ }^{12.18}$

The role of friends can also be considered a positive factor, given their importance in the life of adolescents. Young people feel more comfortable talking about various subjects, including sex and sexuality, and feel supported to return to consultations and seek therapeutic assistance in the company of friends. Thus, in addition to increasing support for families and caregivers, it is important to improve strategies targeted at peers. Two of them are counseling and voluntary testing since these favor the approximation between the adolescents and their families, communities, peers, and services. ${ }^{19}$

However, the support of friends is seen as more relevant to teenagers who become infected through sex or blood, because many parents, caregivers, and professionals demonstrate greater care with those infected by vertical transmission, providing, therefore, greater support for them. This leads us to reflect on the symbolic representation of being infected by one's mother or by other means, such as the emotional involvement of professionals and family members, the need to live with the condition from birth, and the high incidence and mortality of transplacental cases. ${ }^{20}$

Limited life conditions as a result of HIV seropositivity may influence psychosocial development, cognitive maturity, and even decrease of pubertal maturation. However, these adolescents need to recognize their condition and the importance of erotic and seductive play using condoms, thus reducing the risk of transmission. It is necessary to support subsidies so that these adolescents can have autonomy and be responsible for their decisions and sexual behaviors. To achieve that it is necessary to increase the discussion around the topic and expand the scope of research on the risks and problems to which this population is exposed. ${ }^{21}$

Parents and caregivers have difficulty in establishing a dialog about sex and sexuality with these adolescents, who still turn to friends for support and answers. ${ }^{22}$ It is necessary to strengthen and adjust initiatives involving caregivers and family members, focusing on their physical, psychological, and social well-being and, consequently, providing positive support for adolescents with HIV, thus improving the quality of life of parents, carers, children and adolescents. ${ }^{23}$

Communication between parents and adolescents can, directly and indirectly, influence their attitudes, beliefs, intentions, and behaviors towards sex and condoms. Therefore, it is necessary to identify the communication barriers so that it becomes increasingly effective, thus minimizing the risks and enabling a healthy sex life. ${ }^{24}$ Studies developed in Ghana and Tanzania have shown that dialogs between parents and adolescents have grown considerably, particularly concerning the use of condoms and sex. However, it is necessary to expand research on the dialog between children and parents. ${ }^{22}$

Critical and reflexive dialog enables the critical thinking and empowerment of individuals and communities, thus impacting the promotion of health and determinants of health, disease, and care, particularly in South America, which requires changes in the living conditions and health of the population. Self-determination towards change is related to empowerment, which is understood as a social, cultural, psychological 
and/or political process that can take place at an individual or community level. ${ }^{24}$

\section{CONCLUSION}

Care for HIV seropositive adolescents, as well as to their family members and caregivers, must involve psychological and emotional support, awareness about the treatment, changes in lifestyle and habits, promotion of quality of life, healthy sexuality, use of condoms, combat against prejudice, discrimination, and social isolation.

It is necessary to carry out new studies that allow knowing and comparing results that can assist in the decision making of health policies to the prevention and assistance of adolescents in the midst of the HIV/ AIDS pandemic in Brasil and in Latin America.

The scarcity of research on the topic leads us to reflect on some aspects, such as: limited experience in the treatment of children and adolescents, the irrelevance of the problem in South American countries, lack of scientific production in many countries, as well as the possibility of the descriptors used not being indexed in the DeCS or not portraying the content of the research.
Regarding the implications and contributions to practice, the research highlights the need for care initiatives with goals and objectives that enhance interdisciplinary actions guided by scientific knowledge, focusing on the particularities of different cultures, values, and beliefs of adolescents and their families in the context of stigma, prejudices, social isolation and recovery of resilience, social support, and empowerment.

\section{ACKNOWLEDGMENTS}

This paper is part of the studies carried out during a post-doctoral internship funded by Capes at the Tulane University, in the United States. Therefore, we would like to thank both institutions for the incentive and opportunity to develop research in the area of adolescence, as well as Dr. Bernard Carl Kendall and Dr. Ligia Regina Franco Sansigolo Kerr for their teachings.

\section{Author's Contribution}

All authors contributed equally to this study.

Statement of conflict of interests

Nothing to declare.

\section{RESUMO}

OBJETIVO: Analisar as evidências científicas acerca da revelação diagnóstica de adolescentes infectados pelo HIV/aids no contexto sul-americano.

FONTES DE DADOS: Revisão sistemática da literatura nas bases de dados PubMed, Cinahal, Embase, Cochrane, BVS e Global Health, utilizando os descritores adolescent and HIV and family and Argentina or Bolivia or Brasil or Chile or Colombia or Equador or French Guiana or Paraguay or Peru or Uruguay or Venezuela.

SÍNTESE DOS DADOS: O Brasil foi o país de destaque. Verificou-se que os pais exercem influência direta e indireta sobre a vida dos adolescentes, especialmente com relação aos comportamentos e cuidados de saúde. O diálogo entre os membros da família pode reduzir a vulnerabilidade dos adolescentes ao HIV e encorajar a revelação do diagnóstico.

CONCLUSÃO: É necessário ampliar a pesquisa envolvendo adolescentes, pais/cuidadores, famílias com HIV/aids para melhorar os cuidados e reduzir os casos da doença. Sugere-se que as políticas de prevenção e tratamento envolvam famílias, cuidadores, parceiros e comunidades.

PALAVRAS-CHAVE: Família. Adolescente. HIV. América do Sul.

\section{REFERENCES}

1. Jucá VS, Vorcaro AMR. Adolescence and adolescents in acts in the psychoanalytic clinic. Psicol USP. 2018;29(2):246-52.

2. Alves AMP, Cassim FTR. Sentidos e significados produzidos por adolescentes a respeito da sexualidade: uma pesquisa sócio-histórica. Rev Educação e Linguagens. 2017;6(11):109-33.

3. UNICEF. Bem-estar e privações múltiplas na infância e na adolescência no Brasil. Brasília: Fundo das Nações Unidas para a Infância; 2018.
4. Brasil. Ministério da Saúde. Secretaria de Vigilância em Saúde. Departamento de DST, Aids e hepatites virais. Boletim Epidemiológico-Síflis, 2017. Brasília: Ministério da Saúde; 2017.

5. UNICEF. Pobreza na infância e na adolescência. Brasília: Fundo das Nações Unidas para a Infância; 2017.

6. Ventura |, Ribas T, Gehlen MH, Paula SF, Ferreira CL, Pereira AD. Drug initiation and abuse during adolescence: a narrative review. Rev Fun Care Online. 2018;10(4):1169-75. 
7. Souza ATS, Pinheiro DM, Costa GR, Araújo TME, Rocha SS. As influências socioculturais sobre as doenças sexualmente transmissíveis: análise reflexiva. R Interd. 2015;8(1):240-6.

8. Simões $\mid A$. Gerações, mudanças e continuidades na experiência social da homossexualidade masculina e da epidemia de HIV-Aids. Sex Salud Soc. (Rio J.) 2018;29:313-9.

9. Paula CC, Silva CB, Zanon BP, Brum CN, Padoin SMM. Ética na pesquisa com adolescentes que vivem com HIV/Aids. Rev Bioét. 2015;23(1):161-8.

10. World Health Organization, 2014. Available from: http://www.childrenandaids.org/files/str6_infographic_low_res.pdf

11. Falci SG, Marques LS. CONSORT: when and how to use it. Dental Press | Orthod. 2015;20(3):13-5.

12. Taquette SR, Rodrigues AO, Bortolotti LR. Percepção de pacientes com AIDS diagnosticada na adolescência sobre o aconselhamento pré e pósteste HIV realizado. Ciênc Saúde Coletiva. 2017;22(1):23-30.

13. Garbin CAS, Martins RJ, Belila NM, Garbin AJl. O estigma de usuários do sistema público de saúde brasileiro em relação a indivíduos HIV positivo. DST J Bras Doenças Sex Transm. 2017;29(1):12-6.

14. Garbin CAS, Wakayama B, Saliba TA, Saliba O, Garbin AJl. Discriminación y prejuicio. La influencia del VIH/SIDA y la Hepatitis B en la actitud de los académicos en odontología. Rev Cienc Salud. 2018;16(2):279-93.

15. Silva LC, Felício EEAA, Cassétte JB, Soares LA, Morais RA, Prado TS, et al. Psychosocial impact of HIV/Aids diagnosis on elderly persons receiving care from a public healthcare service. Rev Bras Geriatr Gerontol. 2015;18(4):821-33
16. Padoin SMM, Züge SS, Aldrighi JD, Primeira MR, Santos ÉEP, Paula CC. Mulheres do Sul Brasil em terapia antirretroviral: perfil e o cotidiano medicamentoso. Epidemiol Serv Saúde. 2015;24(1):71-8.

17. Paschoal EP, Santo CCE, Gomes AMT, Santos El, Oliveira DC, Pontes APM Adherence to antiretroviral therapy and its representations for people living with HIV/AIDS. Esc Anna Nery. 2014;18(1):32-40.

18. UNICEF - Fundo das Nações Unidas para a Infância. Child survival -HIV/ AIDS, [Internet]. 2014 [cited 2018 Out 26]. Available from: http://www.unicefusa.org/mission/survival/hivaids?gclid=COOU86Xx1r8CFahj7AodAmkABg

19. Savegnago SDO, Arpini DM. A abordagem do tema sexualidade no contexto familiar: o ponto de vista de mães de adolescentes. Psicol Cienc. 2016;36(1):130-44.

20. Borges JMC, Pinto JA, Ricas J. Crianças e adolescentes vivendo com HIV/ aids: "que doença é essa?". Reverso. 2015;37(70):67-74.

21. Kajula LJ, Sheon N, De Vries H, Kaaya SF, Aarø LE. Dynamics of parentadolescent communication on sexual health and HIV/AIDS in Tanzania. AIDS Behav. 2014;18(Suppl 1):S69-74

22. Sánchez-Domínguez R, Villalobos-Gallegos L, Felix-Romero V, MoralesChainé S, Marín-Navarrete R. Efeito do uso de substâncias no uso do preservativo na Teoria do Comportamento Planejado: Análise do funcionamento diferencial do item. Salud Mental. 2017;40(1):5-14.

23. Campos ACV, Borges CM, Lucas SD, Vargas AMD, Ferreira FE. Empoderamento e qualidade de vida de adolescentes trabalhadores assistidos por uma entidade filantrópica de apoio ao adolescente. Saúde Soc. 2014;23(1):238-50.

24. Fetterman D. Empowerment evaluation at the Stanford University School of Medicine: using a critical friend to improve the clerkship experience. Ensaio: Aval Pol Públ Educ. 2009;17(63):197-204. 